\title{
Towards a Model to Measure Tourism Industry Success (Global Study)
}

\author{
Eng. Omnia Mohamed Mohamed Ahmed ${ }^{1}$, Prof.Dr. Tarek Abdel-Latif Aboul-Atta ${ }^{2}$, \\ Prof.Dr. Asmaa Mohamed Abdel- Aty ${ }^{3}$ \\ ${ }^{1}$ Ph.D., Student, Department of Architecture, Faculty of Engineering, Cairo University, Egypt. \\ ${ }^{2}$ Professor of Architecture and Regional Planning, Department of Architecture, Faculty of Engineering, Cairo University, Egypt. \\ ${ }^{3}$ Professor of Architecture and Regional Planning, Department of Architecture, Faculty of Engineering, Cairo University, Egypt.
}

\begin{abstract}
This research addresses the challenges of tourism industry and its failures in Egypt through the past years despite its multiple touristic potentials and natural resources as compared to other countries with higher visiting tourists` rates and less potentials. From this view, the research aims at determining the most effective variables that influence the success of tourism industry with application on 24 countries including the more and less developed ones, with indication for the effect of each of these significant variables. This was achieved by conducting a statistical analysis for analyzing all these variables and ending up with deducting a model for measuring the predicted degree of success of tourism industry in any country based on the most effective variables that significantly influence the enhancement of the tourism sector and increase its revenues.
\end{abstract}

Keywords:A statistical model of measure tourism industry success, Tourism types, SPSS.

\section{INTRODUCTION}

Tourism and travel industry represents now as a main economic sector in the world and an important trigger that helps economic development and provides many direct and indirect job opportunities. It is also considered as one of the most vital industries that improves the country' economy. Tourism hasexperienced many stages of development, from being a phenomenon, till it has been developed to be science and industry with rules and principles. As a result, manyuntraditional types of tourism has emerged attracting tourists from all countries [1].

The main problem discussed in this paper is that Egypt suffers from economic fluctuations in the tourism industry, despite its various touristic potentials; Egypt has welcomed 11.3 million tourists and earned about 8.9 billiondollars in 2018 , which is a very low ratio compared to the most visited countries in the world [2].
There are some countries that possess many tourism resources, but they cannot attain success in tourism industry. On the other hand, there are some countries that do not have many tourism resources; however, they can attain success in tourism industry. Accordingly, tourism resources only are not sufficient to achieve tourism success in all countries.

In Egypt, tourism industry is not very successful despite having distinguished natural resources and historical civilizations, not less than the most visited countries in the world. Problems relating to tourism sector in Egypt are: low numbers of tourists, it is widely known and categorized as the second cheapest tourist country in the world, low daily spending rate of tourists, poor domestic tourism, poor category of tourists visiting Egypt- most of them are Russians, depending on traditional tourist trends, lack of new touristic trends that attract tourists from all over the world, low level of services and facilities, lack of trained labor in tourism sector, local society poor awareness of how to deal with tourists, touristic promotions are for touristic destination not for the country, and finally lack of regular flights, either Charter Airlines or low cost flights (by foreign or Egyptian companies) [3].

The main objective of this research is to determine all major variables that affect tourism industry success in 24 countries under study including developed and less developed counties in tourism industry; and to know the importance and effect of those variables.

The research hypothesis is the possibility to reach a model to measure the expected tourism success in any country depending on factors affecting it and the strength of these factors.

Research methodology includes:

First -Theoretical background: In this stage, we should learn about the 24 countries under study including developed and less developed counties in tourism industry; and compile studies that dealt with variables affecting tourism industry success.

Second - Empirical study: In this stage a touristic study will be conducted on 24 countries in general, applying variables 
that influence tourism industry success in those countries. Then, six of those countries will be studied in detail using a statistical model in order to reach the most influential variables and their effect in those countries, to deduce a statistical model to measure the tourism industry success in the countries.

The Statistical Package for the Social Sciences (SPSS) is a widely used program for statistical analysis in social sciences, particularly in education and research. However, because of its potential, it is also widely used by market researchers, health-care researchers, survey organizations, governments, most notably, data miners and big data professionals.

\section{THEORETICAL STUDY}

It includes the theoretical frame work using the inductive approach. The paper will utilize this approach to study the following:

\subsection{Tourism Definition}

Tourism is the transfer of tourists whether individually or collectively with the aim of relaxation that ends by returning back to departure point. Tourism is about two destinations: departure and arrival.

\subsection{Advantages of Tourism}

It is considered an economic and investment factor that provides many direct and indirect job opportunities, main source of developing other economic sectors, tourist expenditure helps increasing foreign currencies in the country, increasing the gross production of the country, it has a significant role in social development, and finally it helps in cultural varieties [3].

\subsection{The Effect of Touristic Products Variety}

The touristic products variety would enhance competitiveness of destination through various experiences and activities, promote the value of destination through uplifting tourist experience about that destination, and attract tourists of other nationalities [3].

\subsection{Tourism Types}

Tourism types which include traditional tourism types, and modern Tourism types, this will be detected as follows.

\subsubsection{Traditional tourism types}

Traditional tourism types such as Heritage Tourism, Recreation Tourism, and Meditation Tourism.

\subsubsection{Modern Tourism types}

Modern tourism types such as Adventure Tourism, Business Tourism, Space Tourism, Shopping Tourism, Luxury Commodities Tourism, Movies Tourism, Festivals Tourism, Disabled Tourism, Rewarding Tourism, Weekend Tourism, Safari Tourism, Yacht Tourism, Cars Tourism, Scientific (Research) Tourism, Snowboarding Tourism, and finally
Sand Boarding Tourism to induce untraditional Tourism types all over the world [3].

\subsection{The Scientific Studies Discussing Variables Affecting Tourism Industry Success in World's States}

This research reviews a previous Ph.D., in Architectural Engineering Department,Faculty of Engineering, Menoufia University, to identify the variables affecting tourism industry success which are 71 variables. Afterwards, it discusses the main variables that cover the following aspects natural, economic, urban, social, information technology infrastructure, security and safety, transport and communication, competitive tourism and travel prices, health, and finally public services [4].

\subsection{The Countries Under Study}

The countries under study include the developed and less developed ones in achieving success in tourism industry, which are France, Spain, United States, China, Italy, United Kingdom, Germany, Ukraine, Turkey, Mexico, India, Egypt, Japan, South Korea, Indonesia, Brazil, Austria, Russia, Thailand, Singapore, Tunisia, Morocco, Malaysia, and finally Australia [5].

\subsection{Study of Variables Affecting Success of Tourism Industry in Countries Under Study}

In France the following variables are valorized. The diversity of surface features, the diverse of climate, diverse of new touristic patterns, diverse of traditional tourism, the value of the state's currency vs., the diverse economic activities, the diverse economic activities, variety of touristic milestones, variety of religions and fuel prices.

In Spain the following variables are valorized. The diversity of surface features, diverse of new touristic patterns, diverse of traditional tourism, the value of the state's currency vs., the variety of activities that tourists, the diverse economic activities, variety of touristic milestones, multiculturalism, variety of transportation and variety of public services.

In United States the following variables are valorized. The diverse of surface features, The diverse of climate, number of natural reserves, diverse of new touristic patterns, diverse of traditional tourism, average number of nights tourists spend, gross national income, the value of the state's currency vs., tourism expenditure, the variety of activities that tourists,the diverse economic activities, average of annual income per capita, area, size of railway network, size of road networks, number of hotels, number of hotel rooms, population, variety of religions, indication of human development, multiculturalism, number of internet users, number of mobile phones, number of Transportation means per 1000 persons and number of airports.

In China the following variables are valorized. Number of natural reserves, diverse of traditional tourism, gross national income, foreign-exchange reserves, tourism expenditure, number of employees in tourism,area, size of railway network, size of road networks, number of hotel rooms, population, languages variations, variety of religions, number of internet users, number of mobile phones, price of 
flight tickets (round trip) from Egypt to most visited countries and quality of health as described by world health organization.

In Italy the following variables are valorized. The diverse of surface features, diverse of new touristic patterns, diverse of traditional tourism, diverse of tourists nationalities, the value of the state's currency vs., the variety of activities that tourists, the diverse economic activities, average of annual income per capita, number of hotels, variety of touristic milestones, percentage of conductors, variety of transportation, number of transportation means per 1000 persons, fuel prices, average age and variety of public services.

In United Kingdom the following variables are valorized. The diverse of Climate, diverse of traditional tourism, the value of the state's currency vs., the diverse economic activities, variety of religions and the lowest number of traffic fatalities.

In Germany the following variables are valorized. The diverse of Climate, diverse of traditional tourism, the value of the state's currency vs., tourism expenditure, quality of infrastructure, languages variations, variety of religions, fuel prices, average age and mortality rate.

In Ukraine the following variables are valorized. The diverse of Climate, diversity of traditional tourism, average number of nights tourists spend, the diverse economic activities, percentage of conductors, number of ports and mortality rate.

In Turkey the following variables are valorized. The diverse of surface features, diverse of new touristic patterns, diverse of traditional tourism, diverse of tourists nationalities, the variety of activities that tourists, the diverse economic activities, multiculturalism, variety of transportation and number of ports.

In Mexico the following variables are valorized. diverse of traditional tourism, multiculturalism, number of airports, number of ports and total renewable water resources.

In India the following variables are valorized. The diverse of surface features, The diverse of Climate, number of employees in tourism, size of road networks, population, languages variations, variety of religions, number of internet users and number of mobile phones.

In Egypt the following variables are valorized. diverse of traditional tourism, the diverse economic activities and variety of transportation.

In Japan the following variables are valorized. The diverse of climate, gross national income, foreign-exchange reserves, quality of infrastructure, number of hotel rooms, the lowest number of traffic fatalities and average age.

In South Korea the following variables are valorized. Diverse of new touristic patterns, diverse of traditional tourism, tourist expenditure per day and variety of public services.
In Indonesia the following variables are valorized. Diverse of new touristic patternsandnumber of employees in tourism.

In Brazil the following variables are valorized. The diverse of climate, diverse of new touristic patterns, diverse of traditional tourism, number of hotels, variety of religions, number of airports and price of flight tickets (round trip) from Egypt to most visited countries.

In Austria the following variables are valorized. The diverse of climate, diverse of traditional tourism, the value of the state's currency vs., quality of infrastructure, variety of transportation and variety of public services.

In Russia the following variables are valorized. The diverse of climate, foreign, exchange reserves, area, percentage of conductors, variety of transportation, quality of health as described by world health organization, mortality rate and variety of public services.

In Thailand the following variables are valorized. Average number of nights tourists spend, diverse of tourists nationalities, the diverse economic activities and total renewable water resources.

In Singapore the following variables are valorized. Diverse of traditional tourism, tourist expenditure per day, average of annual income per capita, size of railway network, indication of human development and the lowest number of traffic fatalities.

In Tunisia the following variables are valorized. Diverse of traditional tourism and variety of transportation.

Moroccovalorized the following variables. Diverse of traditional tourism, foreign-exchange reserves and tourist expenditure per day.

In Malaysia the following variables are valorized. Diverse of traditional tourism, the variety of activities that tourists, quality of health as described by world health organization and total renewable water resources.

In Australia the following variables are valorized. The diverse of climate, number of natural reserves, diverse of traditional tourism, the diverse economic activities, variety of religions, indication of human development, number of transportation means per 1000 persons, price of flight tickets (round trip) from Egypt to most visited countries and variety of public services.

\section{METHODOLOGY}

This part of the research study will determine the most effective variables that influence the success of tourism industry with application on 24 countries including the more and less developed ones, with indication for the effect of each of these significant variables. This was achieved by conducting a statistical analysis for analyzing all these variables and ending up with deducting a model for measuring the predicted degree of success of tourism industry in any country based on the most effective variables that significantly influence the enhancement of the tourism 
International Journal of Engineering Research and Technology. ISSN 0974-3154, Volume 13, Number 5 (2020), pp. 1009-1018

(C) International Research Publication House. https://dx.doi.org/10.37624/IJERT/13.5.2020.1009-1018

sector and increase its revenues, Fig.1. illustrates the steps of methodology for the analytical and applied study. This is done through:

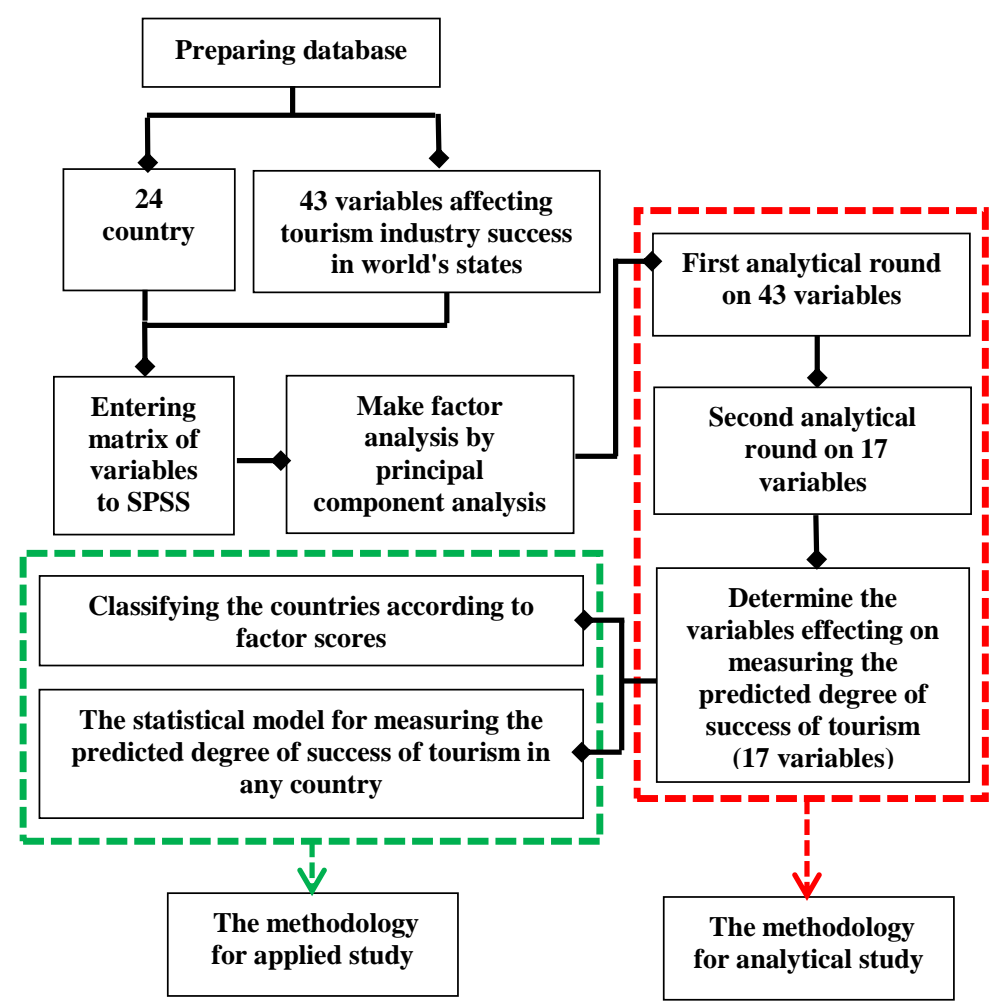

Fig. 1.The methodology steps for analytical and applied study

\subsection{Case Studies Analysis: Tourism Development in 24 Countries}

Comparative analytical approach has been used to shortlist variables that affect tourism industry success in 24 countries including developed and less developed counties in this domain. The number of those variables is 43 after excluding two variables: number of tourists and tourism incometo compare them in terms of tourism industry success.

The 43 variables shown in Table 1 are divided as follows: Three natural variables, 15 economic variables, five urban variables, six social variables, two information technology infrastructure variables, one variable of security and safety, four variables of transport and communication, two variables of competitive tourism and travel prices, four variables of health and one variable of public services, through the following steps to deduce a model to measure the expected tourism success in any country, It depends on identifying factors affecting tourism and their strength:

I- Insert data matrix (43 columns for 43 variables) $* 24$ rows for 24 countries (cases).

II- Conduct a statistical analysis for this matrix in order to obtain results that indicate the existence of strong influential components affecting tourism industry success. Moreover, it clarifies relations ships between these components. In this case, those values represent strong variables inside each component of the matrix. There is also ( $\%$ of total variance) for each component and ratio of change occurred in cases under study to indicate the strength of each component.

III-All major variables affecting tourism industry have been studied in the most visited states in the world. The number of those variables is 43 extracted from previous studies. The 24 countries under study, including developed and less developed countries in achieving success in tourism industry, have been arranged according to the strength of each variable as follows:

(1:24), whereas number 1 represents more powerful variable and then gradually decreases until it reaches number 24 .

Therefore, the results of the equation will be divided by 10 to represent the level of achieving success in tourism industry. Table 1 shows only six states arranged out of the 24 countries under study, as a sample of results.

Table 1. Indicates variables that affect tourism industry success in six developed and less developed countries in tourism industry [6-24].

\begin{tabular}{|c|l|c|c|c|c|c|c|}
\hline \multicolumn{2}{|c|}{ Variables } & France & $\begin{array}{c}\text { United } \\
\text { States }\end{array}$ & India & Egypt & Japan & Morocco \\
\hline \multirow{4}{*}{$\begin{array}{c}\text { Natural } \\
\text { Variables }\end{array}$} & 1-The diverse of surface features & 1 & 2 & 1 & 6 & 8 & 7 \\
\cline { 2 - 8 } & 2-The diverse of Climate & 3 & 3 & 2 & 5 & 1 & 2 \\
\cline { 2 - 8 } & 3-Number of natural reserves & 19 & 3 & 20 & 7 & 17 & 17 \\
\hline \multirow{5}{*}{$\begin{array}{c}\text { Economic } \\
\text { Variables }\end{array}$} & 4-Diverse of new touristic patterns & 2 & 3 & 5 & 1 & 6 & 4 \\
\cline { 2 - 8 } & 5-Diverse of traditional tourism types & 2 & 3 & 4 & 3 & 5 & 3 \\
\cline { 2 - 8 } & 6-Average number of nights tourists spend & 5 & 1 & 9 & 4 & 8 & 5 \\
\cline { 2 - 8 } & 7- Diverse of tourists nationalities & 8 & 8 & 6 & 4 & 8 & 9 \\
\hline
\end{tabular}


International Journal of Engineering Research and Technology. ISSN 0974-3154, Volume 13, Number 5 (2020), pp. 1009-1018

(C) International Research Publication House. https://dx.doi.org/10.37624/IJERT/13.5.2020.1009-1018

\begin{tabular}{|c|c|c|c|c|c|c|c|}
\hline \multirow{7}{*}{$\begin{array}{l}\text { Economic } \\
\text { Variables }\end{array}$} & 9-The value of the state's currency vs. USD & 12 & 14 & 4 & 20 & 2 & 2 \\
\hline & 10-Foreign-exchange reserves & 12 & 14 & 4 & 20 & 2 & 2 \\
\hline & 11-Tourism expenditure & 4 & 2 & 15 & 24 & 12 & 24 \\
\hline & 12-tourist expenditure per day & 11 & 6 & 23 & 20 & 16 & 3 \\
\hline & $\begin{array}{l}\text { 13-The variety of activities that tourists } \\
\text { carry out }\end{array}$ & 4 & 2 & 8 & 8 & 7 & 10 \\
\hline & 14-Number of employees in tourism sector & 14 & 4 & 3 & 7 & 15 & 13 \\
\hline & 15- Variety of economic activities & 1 & 3 & 5 & 2 & 6 & 5 \\
\hline \multirow{5}{*}{$\begin{array}{l}\text { Economic } \\
\text { Variables }\end{array}$} & 16-Average of annual income per capita & 4 & 1 & 24 & 18 & 10 & 19 \\
\hline & 17-Area & 14 & 2 & 6 & 9 & 17 & 11 \\
\hline & 18-Size of railway network & 9 & 1 & 5 & 17 & 10 & 23 \\
\hline & 19-Size of road networks & 7 & 1 & 2 & 20 & 6 & 22 \\
\hline & 20-Quality of infrastructure & 7 & 5 & 17 & 12 & 2 & 22 \\
\hline \multirow[b]{3}{*}{ Urban Variables } & 21-Number of hotels & 5 & 3 & 13 & 10 & 19 & 17 \\
\hline & 22-Number of hotel rooms & 10 & 1 & 17 & 16 & 3 & 13 \\
\hline & 23-Variety of touristic milestones & 3 & 12 & 12 & 4 & 11 & 7 \\
\hline \multirow{6}{*}{ Social Variables } & 24-Population & 14 & 13 & 2 & 9 & 7 & 19 \\
\hline & 25-Languages variations & 11 & 5 & 1 & 11 & 12 & 9 \\
\hline & 26-Variety of religions & 3 & 3 & 1 & 6 & 4 & 5 \\
\hline & 27-Percentage of Conductors & 4 & 4 & 20 & 18 & 7 & 19 \\
\hline & 28-Indication of human development & 8 & 2 & 22 & 20 & 5 & 21 \\
\hline & 29-Multiculturalism & 5 & 1 & 6 & 4 & 7 & 6 \\
\hline $\begin{array}{l}\text { Security and } \\
\text { Safety }\end{array}$ & 30-The lowest number of traffic fatalities & 5 & 10 & 15 & 24 & 2 & 22 \\
\hline Public Services & 31-Variety of public services & 9 & 8 & 9 & 6 & 8 & 8 \\
\hline \multirow{2}{*}{$\begin{array}{l}\text { Information } \\
\text { technology } \\
\text { infrastructure }\end{array}$} & 32-Number of internet users & 11 & 3 & 2 & 14 & 5 & 20 \\
\hline & 33-Number of mobile phones & 15 & 3 & 2 & 11 & 7 & 20 \\
\hline \multirow{4}{*}{$\begin{array}{c}\text { Transport and } \\
\text { communication } \\
\text { Variables }\end{array}$} & 34-Variety of transportation & 6 & 4 & 6 & 3 & 5 & 5 \\
\hline & \begin{tabular}{|l|}
$\begin{array}{l}35-N u m b e r \\
1000 \text { persons }\end{array}$ \\
\end{tabular} & 6 & 1 & 23 & 22 & 5 & 20 \\
\hline & 36-Number of airports & 7 & 1 & 12 & 20 & 13 & 21 \\
\hline & 37-Number of ports & 7 & 5 & 7 & 7 & 5 & 8 \\
\hline \multirow{2}{*}{$\begin{array}{c}\text { Competitiveness } \\
\text { of tourism and } \\
\text { travel prices }\end{array}$} & $\begin{array}{l}\text { 38-Price of flight tickets (round trip) from } \\
\text { Egypt to most visited countries }\end{array}$ & 19 & 8 & 13 & - & 7 & 22 \\
\hline & 39-Fuel prices & 2 & 15 & 10 & 20 & 8 & 9 \\
\hline \multirow{4}{*}{ Health variables } & $\begin{array}{l}\text { 40-Quality of health as described by World } \\
\text { Health Organization }\end{array}$ & 24 & 15 & 5 & 10 & 19 & 17 \\
\hline & 41-Average age & 6 & 11 & 22 & 23 & 2 & 19 \\
\hline & 42-Mortality rate & 8 & 10 & 12 & 22 & 6 & 23 \\
\hline & 43-Total renewable water resources & 8 & 20 & 23 & 15 & 4 & 17 \\
\hline
\end{tabular}


International Journal of Engineering Research and Technology. ISSN 0974-3154, Volume 13, Number 5 (2020), pp. 1009-1018

(C) International Research Publication House. https://dx.doi.org/10.37624/IJERT/13.5.2020.1009-1018

IV-The statistical analysis has been applied on the 43 variables in the first round through SPSS package. In this case, all variables are considered to be influential in tourism success if they exceed 0,5; i.e.: it is influential in making change by $50 \%$ or more. Thus, in the second round, the statistical analysis has been applied through SPSS package to reach more accurate results to identify the most influential major variables in tourism industry success in the 24 countries under study, as the component is reanalyzed to attain (Eigen Value) that reflects saturation of the variable in each component. In this case, variables' value with more than 0.5 are equal to the number of components which are 17 variables, as shown in Table 2.

Table 2. Shows the ratio of variance explained for the statistical analysis of the variables that affect success of the tourism industry in countries subject of the study in the second run of the statistical analysis using the SPSS Package.

\begin{tabular}{|c|c|c|c|c|c|c|}
\hline \multirow[b]{2}{*}{ Component } & \multicolumn{3}{|c|}{ Initial Eigen values } & \multicolumn{3}{|c|}{ Extraction Sums of Squared Loadings } \\
\hline & $\%$ Cumulative & $\begin{array}{c}\text { \%of } \\
\text { Variance }\end{array}$ & (Total) & $\%$ Cumulative & $\begin{array}{c}\% \text { of } \\
\text { Variance }\end{array}$ & (Total) \\
\hline 1 & 47.678 & 47.678 & 9.059 & 47.678 & 47.678 & 9.059 \\
\hline 2 & 61.841 & 14.164 & 2.691 & 61.841 & 14.164 & 2.691 \\
\hline 3 & 77.53 & 7.501 & 1.425 & 77.53 & 7.501 & 1.425 \\
\hline 4 & 82.38 & 4.85 & 0.921 & & & \\
\hline 5 & 86.784 & 4.404 & 0.837 & & & \\
\hline 6 & 89.833 & 3.048 & 0.579 & & & \\
\hline 7 & 92.377 & 2.545 & 0.484 & & & \\
\hline 8 & 94.614 & 2.236 & 0.425 & & & \\
\hline 9 & 96.367 & 1.754 & 0.333 & & & \\
\hline 10 & 97.526 & 1.158 & 0.22 & & & \\
\hline 12 & 99.049 & 0.614 & 0.117 & & & \\
\hline 13 & 99.381 & 0.332 & 0.063 & & & \\
\hline 14 & 99.663 & 0.283 & 0.054 & & & \\
\hline 15 & 99.918 & 0.101 & 0.019 & & & \\
\hline 16 & 99.96 & 0.042 & 0.008 & & & \\
\hline 17 & 100 & 0.04 & 0.008 & & & \\
\hline
\end{tabular}

Table 2 indicates the total variance explained, indicating that the most representative components for the variance are the first four ones where eigen value decreases gradually from one component to another. The first component shows the largest value $47.678 \%$ where its variables indicate that they are the most represented, due to a difference or a clear variance.
$\mathrm{V}$ - Matrix of components in Table 3 indicates 4 components whose numbers represent the influence of each variable upon each component; descending arranged. Different values of variables will be listed according to its influence strength on each component. The most influential variables in the rate of change relating to tourism industry success are found to be those included in the first component that exceeds 0.5 , i.e.: they affect change by $50 \%$ or more.

Table 3. Indicates components of second run through component analysis of variables that affect tourism industry success in 24 countries understudy using the SPSS Package.

\begin{tabular}{|c|c|c|c|c|}
\hline Variables & 1 & 2 & 3 & 4 \\
\hline Number of airports & 0.803 & -0.26 & -0.283 & 0.096 \\
\hline Number of mobile phones & 0.8 & -0.311 & 0.039 & -0.185 \\
\hline Number of hotel rooms & 0.785 & -0.14 & -0.169 & 0.303 \\
\hline The value of the state's currency vs. USD & 0.781 & -0.298 & 0.066 & -0.448 \\
\hline Diverse of new touristic patterns & 0.775 & 0.526 & -0.7 & -0.061 \\
\hline Variety of economic activities & 0.771 & -0.219 & 0.156 & -0.361 \\
\hline
\end{tabular}


International Journal of Engineering Research and Technology. ISSN 0974-3154, Volume 13, Number 5 (2020), pp. 1009-1018

(C) International Research Publication House. https://dx.doi.org/10.37624/IJERT/13.5.2020.1009-1018

\begin{tabular}{|l|c|c|c|c|}
\hline The lowest number of traffic fatalities & 0.756 & -0.424 & -0.373 & -0.14 \\
\hline Quality level of infrastructure & 0.752 & -0.491 & -0.091 & 0.157 \\
\hline $\begin{array}{l}\text { Number of direct and indirect } \\
\text { employees in tourism sector }\end{array}$ & 0.748 & -0.009 & 0.226 & 0.266 \\
\hline Number of hotels & 0.638 & 0.109 & 0.331 & -0.574 \\
\hline Population & 0.605 & 0.449 & 0.394 & 0.226 \\
\hline Variety of touristic milestones & 0.604 & 0.438 & 0.243 & 0.181 \\
\hline Number of natural reserves & 0.6 & -0.367 & 0.125 & 0.061 \\
\hline Diverse of religions & 0.595 & 0.484 & -0.418 & -0.095 \\
\hline Number of transportations per 1000 persons & 0.521 & 0.777 & -0.027 & -0.145 \\
\hline Fuel prices & 0.571 & 0.033 & 0.629 & 0.202 \\
\hline Average of annual income per capita & 0.5 & 0.418 & -0.520 & 0.191 \\
\hline
\end{tabular}

VI - Statistical analysis provides an assessment for each case which is called (factor scores) that resulted in four components. In this analysis, the first component has been used to arrange countries according from their level of success in tourism industry success, as indicated in Table 4.

Table 4. Indicates arrangement of the 24 countries under study according to their success in tourism industry and resulting from the first component according to the second run using the SPSS Package.

\begin{tabular}{|c|c|}
\hline State & Factor score comp 1 \\
\hline Spain & 153 \\
\hline France & 151 \\
\hline China & 103 \\
\hline Italy & 79 \\
\hline Germany & 76 \\
\hline Turkey & 71 \\
\hline United Kingdom & 71 \\
\hline Thailand & 65 \\
\hline United States & 57 \\
\hline Austria & 53 \\
\hline Australia & 37 \\
\hline South Korea & 32 \\
\hline India & -8 \\
\hline Japan & -21 \\
\hline Malaysia & -46 \\
\hline Singapore & -55 \\
\hline Mexico & -74 \\
\hline Russia & -77 \\
\hline Morocco & -100 \\
\hline Egypt & -105 \\
\hline Indonesia & -126 \\
\hline Ukraine & -136 \\
\hline Brazil & -145 \\
\hline Tunisia & -156 \\
\hline
\end{tabular}


International Journal of Engineering Research and Technology. ISSN 0974-3154, Volume 13, Number 5 (2020), pp. 1009-1018

(C) International Research Publication House. https://dx.doi.org/10.37624/IJERT/13.5.2020.1009-1018

Table 4 indicates that there is an obvious difference and contradiction between values of tourism industry success for the 24 countries under study. Spain is ranked on top with score 153, followed by France with 151, whereas Tunisia comes at the end with -156 .

\subsection{A Statistical Model to Measure the Tourism Industry Success in the Countries}

Through analyzing the 24 countries and identifying variables that affect their tourism industry success, and deducing a statistical model that determine the most influential variables, their effects on tourism industry success in those countries. This model can be used to measure tourism industry success in the countries (Y), as indicated in Table 5:
Dependent variablein model 1: Factor score comp 1.

Variables entered in model 1: All the main variables that affect tourism industry success in the 24 countries under study.

Predictors: Constant for all the main variables that affect tourism industry success in the 24 countries under study $($ Constant $=2.162)$.

A1, a2, a3, a4, a5, a6, a7, a8, a9, a10, a11, a12, a13, a14, a15, a16 and a17 are Standardized Coefficients (Beta).

$\mathrm{X} 1, \mathrm{x} 2, \mathrm{x} 3, \mathrm{x} 4, \mathrm{x} 5, \mathrm{x} 6, \mathrm{x} 7, \mathrm{x} 8, \mathrm{x} 9, \mathrm{x} 10, \mathrm{x} 11, \mathrm{x} 12, \mathrm{x} 13, \mathrm{x} 14$ $\mathrm{x} 15, \mathrm{x} 16$ and $\mathrm{x} 17$ are the main variables that affect the success of the tourism industry in developed and less developed countries regarding this field for the countries.

Table 5. Indicates statistical model to measure tourism industry success in 24 countries under study using the SPSS Package.

\begin{tabular}{|c|c|c|c|c|c|}
\hline Variables $(\mathrm{X})$ & $\begin{array}{l}\text { Unstandardized } \\
\text { Coefficients }\end{array}$ & $\begin{array}{l}\text { Standardized } \\
\text { Coefficients }\end{array}$ & Total & \multicolumn{2}{|c|}{ Sing. } \\
\hline $\mathrm{B}$ & Sid. Error & Beta (a) & & & \\
\hline 1 & Constant (C) & 2.162 & 0.913 & 2.368 & 0.056 \\
\hline$\left(\mathrm{X}_{1}\right)$ Number of airports & 0.028 & $\left(\mathrm{a}_{1}\right) 0.031$ & 0.412 & 0.917 & 0.394 \\
\hline$\left(\mathrm{X}_{2}\right)$ Number of mobile phones & -0.033 & $\left(\mathrm{a}_{2}\right) 0.04$ & -0.379 & -0.839 & 0.433 \\
\hline$\left(\mathrm{X}_{3}\right)$ Number of hotel rooms & -0.029 & $\left(\mathrm{a}_{3}\right) 0.033$ & -0.399 & -0.866 & 0.42 \\
\hline$\left(\mathrm{X}_{4}\right)$ Value of State's currency vs. USD & -0.019 & $\left(\mathrm{a}_{4}\right) 0.101$ & -0.062 & -0.188 & 0.857 \\
\hline$\left(\mathrm{X}_{5}\right)$ Variety of new touristic patterns & -0.014 & (a5) 0.019 & -0.182 & -0.723 & 0.497 \\
\hline$\left(\mathrm{X}_{6}\right)$ Variety of economic activities & -0.018 & $\left(a_{6}\right) 0.06$ & -0.126 & -0.293 & 0.779 \\
\hline$\left(\mathrm{X}_{7}\right)$ The lowest number of traffic fatalities & -0.038 & $\left(\mathrm{a}_{7}\right) 0.065$ & -0.551 & -0.584 & 0.581 \\
\hline$\left(\mathrm{X}_{8}\right)$ Quality level of infrastructure & -0.009 & $\left(\mathrm{a}_{8}\right) 0.04$ & -0.133 & -0.225 & 0.829 \\
\hline $\begin{array}{c}\left(\mathrm{X}_{9}\right) \text { Number of direct and indirect employees in } \\
\text { tourism sector }\end{array}$ & 0.007 & (a9) 0.033 & 0.1 & 0.223 & 0.831 \\
\hline$\left(\mathrm{X}_{10}\right)$ Hotels number & 0.022 & $\left(\mathrm{a}_{10}\right) 0.036$ & 0.321 & 0.612 & 0.563 \\
\hline$\left(\mathrm{X}_{11}\right)$ Population & -0.02 & $\left(a_{11}\right) 0.038$ & -0.299 & -0.541 & 0.608 \\
\hline$\left(\mathrm{X}_{12}\right)$ Variety of touristic milestones & -0.137 & $\left(\mathrm{a}_{12}\right) 0.08$ & -0.453 & -1.723 & 0.136 \\
\hline$\left(\mathrm{X}_{13}\right)$ Diverse of natural reserves & -0.005 & $\left(\mathrm{a}_{13}\right) 0.097$ & -0.017 & -0.049 & 0.963 \\
\hline$\left(\mathrm{X}_{14}\right)$ Diverse of religions & -0.028 & $\left(\mathrm{a}_{14}\right) 0.038$ & -0.359 & -0.743 & 0.486 \\
\hline $\begin{array}{c}\left(\mathrm{X}_{15}\right) \text { Number of transportations per } 1000 \\
\text { persons }\end{array}$ & -0.003 & $\left(a_{15}\right) 0.032$ & -0.049 & -0.104 & 0.921 \\
\hline$\left(\mathrm{X}_{16}\right)$ Fuel prices & 0.005 & $\left(\mathrm{a}_{16}\right) 0.035$ & 0.075 & 0.147 & 0.888 \\
\hline$\left(\mathrm{X}_{17}\right)$ Average of annual income per capita & 0.019 & $\left(\mathrm{a}_{17}\right) 0.034$ & 0.278 & 0.562 & 0.594 \\
\hline
\end{tabular}

It can be concluded from Table 5 that the statistical model to measure tourism industry success in the countries is as follows:

$Y=10 /(0.031 * X 1+0.04 * X 2+0.033 * X 3+0.101 * X 4+$ $0.019 * X 5+0.06 * X 6+0.065 * X 7+0.04 * X 8+0.033 * X 9$ $+0.03 * X 10+0.038 * X 11+0.08 * X 12+0.097 * X 13+$ $0.038 * X 14+0.032 * X 15+0.035 * X 16+0.034 * X 17+$ 2.162) (1).

\subsection{The Application of the Proposed Model to Measure the Expected Tourism Success in Italy and Morocco}

This section presents the application of equation number (1) to Italy through compensating the value of the most affecting 17 variables $(\mathrm{X} 1: \mathrm{X} 17)$ on tourism industry as a result of the statistical analysis of the variables affecting tourism industry in the 24 countries under study, as shown in equation number (2). 
International Journal of Engineering Research and Technology. ISSN 0974-3154, Volume 13, Number 5 (2020), pp. 1009-1018

(C) International Research Publication House. https://dx.doi.org/10.37624/IJERT/13.5.2020.1009-1018

$Y=10 /(0.031 * 15+0.04 * 11+0.033 * 4+0.101 * 2+$ $0.019 * 3+0.06 * 3+0.065 * 9+0.04 * 9+0.033 * 9+0.03 *$ $1+0.038 * / 14+0.08 * 1+0.097 * 8+0.038 * 4+0.032 * 3+$ $0.035 * 1+0.034 * 3+2.162)=1.5[6-24](2)$.

Since Italy's Y is bigger than 1.

Similarly, below (as shown in equation number (3)) is the application of equation number (1) to Morocco through compensating the value of the most affecting 17 variables (X1:X17) on tourism industry as a result of the statistical analysis of the variables affecting tourism industry in the 24 countries under study.

$Y=10 /(0.031 * 21+0.04 * 20+0.033 * 13+0.101 * 2+$ $0.019 * 2+0.06 * 5+0.065 * 22+0.04 * 22+0.033 * 13+$ $0.03 * 17+0.038 * 19+0.08 * 7+0.097 * 17+0.038 * 5$ $+0.032 * 20+0.035 * 9+0.034 * 19+2.162)=0.8[6-24]$ (3).

Since Morocco's Y is smaller than 1.

Since the success of tourism industry (Y) in Italy is more than that in Morocco. Italy is more successful in the tourism industry than Morocco. The number of tourists visiting Italy reaches 94 million and tourism revenues are 46,2 billion dollars in 2018 [25]. The number of tourists visiting Morocco reaches 12.5 million and tourism revenues are 7.5 billion dollars in 2018 [26]. Comparing values in the two countries proves the validity of the proposed model measuring the suggested success of tourism in any country.

\section{CONCLUSION}

Through research study of the variables that affect the success of the tourism industry in developed and less developed countries and their statistical analysis using the SPSS Package, a statistical model was developed to measure the success of the tourism industry in these countries with indication in the main and most influential variables in the tourism industry in all countries.

\section{RECOMMENDATION}

The research study recommends using this statistical model for decision-makers in countries which can measure the predicted degree of success of tourism industry in any country based on the most effective variables that significantly influence the enhancement of the tourism sector and increase its revenues.

\section{REFERENCES}

[1] Debees, Y., "Tourism: Definition and Various Types ", Tourism and Museums Series, Creativity and Development Forum in Egypt,No.9, 2010.

[2] Egypt has welcomed 11.3 million tourists and earned about 8.9 billion dollars in 2018, http://gate.ahram.org.eg/News/2239011.aspx, [Accessed 29 June 2018].
[3] El-Gendy, A., "National Plan for a Sustainable Tourism Development Strategy 2020, Local Tourist Products Development Plan", Tourism Development Authority, Ministry of Tourism, Giza, Egypt, 2010.

[4] Alshami, A., "Towards A Methodology to Raise Competitiveness of Tourism Sector in Egypt", Ph.D., Architectural Engineering Department, Faculty of Engineering, Menoufia University, Egypt, 2013.

[5] Most tourist countries in the world, https://www.rjeem.com/\%D8\%A3\%D9\%83\%D8\%AB $\% \mathrm{D} 8 \% \mathrm{~B} 1-$ $\% \mathrm{D} 8 \% \mathrm{~A} 7 \% \mathrm{D} 9 \% 84 \% \mathrm{D} 8 \% \mathrm{AF} \% \mathrm{D} 9 \% 88 \% \mathrm{D} 9 \% 84-$ \%D8\%B3\%D9\%8A\%D8\%A7\%D8\%AD\%D8\%A9$\% \mathrm{D} 9 \% 81 \% \mathrm{D} 9 \% 8 \mathrm{~A}-$ $\%$ D8\%A7\%D9\%84\%D8\%B9\%D8\%A7\%D9\%84\%D9 $\% 85 /$, [Accessed 21 July 2019].

[6] Agarwal, S., "Special Interest Tourism: Concepts, Contexts and Cases", Centre for Agriculture and Bioscience International, United Kingdom, 2018.

[7] Brouder, P., "Tourism Destination Evolution", Routledge, United Kingdom, 2016.

[8] Font, X., "Marketing for Sustainable Tourism", Routledge, United Kingdom, 2019.

[9] Hawkins, R., "Sustainable Tourism", Routledge, United Kingdom, 2016.

[10] Holden, A., "Environment and Tourism", Routledge, United Kingdom, 2016.

[11] Moutinho, L., "Strategic Management in Tourism", Centre for Agriculture and Bioscience International, United Kingdom, 2018.

[12] Pechlaner, H., "Overtourism: Tourism Management and Solutions", Routledge, United Kingdom, 2019.

[13] Economic diversification and its importance for oil countries,

https://annabaa.org/arabic/authorsarticles/7989, [Accessed 21 July 2016].

[14] Prices of gasoline all over the world, https://ar.globalpetrolprices.com/gasoline_prices/, [Accessed 22 September 2019].

[15] Total number of airports by country, http://chartsbin.com/view/1395, [Accessed 21 July 2018].

[16] Median age / Countries of the world, http://world.bymap.org/MedianAge.html, [Accessed 29 January 2017].

[17] Country ranking by 2017 cash reserve, https://www.almrsal.com/post/558964, [Accessed 15 November 2017].

[18] Nature reserves: Egypt's treasures, https://www.almasryalyoum.com/news/details/117177 3, [Accessed 3 August 2017]. 
International Journal of Engineering Research and Technology. ISSN 0974-3154, Volume 13, Number 5 (2020), pp. 1009-1018

(C) International Research Publication House. https://dx.doi.org/10.37624/IJERT/13.5.2020.1009-1018

[19] World tourism revenue in 2015, https://www.argaam.com/ar/article/articledetail/id/439 802, [Accessed 12 August 2016].

[20] How much countries the world spends to attract tourism, https://www.argaam.com/ar/article/articledetail/id/447 974 , [Accessed 8 October 2016].

[21] Dollar price summary chart (USD), https://www.currencyc.com/ar/usdrates.html, [Accessed 10 September 2018].

[22] Of-the-most-important-uses-of-smart-devices and their negatives,https://www.edarabia.com/ar/5-

\%D9\%85\%D9\%86-\%D8\%A3\%D9\%87\%D9\%85-

$\% \mathrm{D} 8 \% \mathrm{~A} 5 \% \mathrm{D} 8 \% \mathrm{~B} 3 \% \mathrm{D} 8 \% \mathrm{AA} \% \mathrm{D} 8 \% \mathrm{AE} \% \mathrm{D} 8 \% \mathrm{AF} \%$

D8\%A7\%D9\%85\%D8\%A7\%D8\%AA-

$\% \mathrm{D} 8 \% \mathrm{~A} 7 \% \mathrm{D} 9 \% 84 \% \mathrm{D} 8 \% \mathrm{~A} 3 \% \mathrm{D} 8 \% \mathrm{AC} \% \mathrm{D} 9 \% 87 \% \mathrm{D}$

$8 \% \mathrm{~B} 2 \% \mathrm{D} 8 \% \mathrm{~A} 9-$

\%D8\%A7\%D9\%84\%D8\%B0\%D9\%83\%D9\%8A\%D8

$\%$ A9-

\%D9\%88\%D8\%B3\%D9\%84\%D8\%A8\%D9\%8A\%D8

$\% \mathrm{~A} 7 \% \mathrm{D} 8 \% \mathrm{AA} \% \mathrm{D} 9 \% 87 \% \mathrm{D} 8 \% \mathrm{~A} 7 /, \quad$ [Accessed 8 September 2019].

[23] The shortage of trained workers is one of the most prominent problems of the tourism sector today, https://www.elwatannews.com/news/details/3386302, [Accessed 23 May 2018].

[24] Tourist patterns in the world, https://www.feedo.net/LifeStyle/TravelTripsRelaxatio n/TourismAllOverWorld.htm, [Accessed 6 August 2019].

[25] Italy outpaces France in the tourism sector, https://arabic.euronews.com/2019/07/20/the-recoveryof-the-tourism-sector-could-make-italy-outperformfrance, [Accessed 20 July 2019].

[26] Morocco is witnessing a boom in tourism despite the killing of the two Scandinavian tourists, https://arabic.euronews.com/2019/01/17/moroccorecords-a-recovery-in-tourism-despite-the-killing-oftwo-scandinavian-tourists, [Accessed 17 January 2019]. 